\title{
Characterization of Metal Ion Complexes with Humic Fractions of Farmyard Manure by Potentiometric Titrations
}

\author{
D. Rajashekhar*, M. Srilatha, P. Chandrasekhar Rao, S. Harish Kumar Sharma and \\ K. Bhanu Rekha
}

Department of soil science and Agricultural chemistry, College of Agriculture, PJTSAU, Rajendranagar, Hyderabad - 500 030, Telangana, India

*Corresponding author

\section{A B S T R A C T}

\section{Keywords}

Farmyard manure (FYM), Humic acid (HA), Fulvic acid (FA), Metal ions and Potentiometric titration

Article Info

Accepted:

26 March 2018

Available Online:

10 April 2018
The present study was carried out at the laboratory, Department of Soil Science and Agricultural Chemistry, College of Agriculture, Rajendranagar to characterize the complex formation of humic fractions with metal ions. The results observed that increase in $\mathrm{pH}$ of humic and fulvic acid when titrated with $0.1 \mathrm{~N} \mathrm{NaOH}$ indicates higher buffering capacity of these fractions. Potentiometric titration curves obtained for both humic and fulvic acids are sigmoidal in shape indicating their weak acid nature. Absence of inflection indicates the formation of metal complexes. Among all the metal ions does not show any inflection with both humic and fulvic acid indicating metal ion forms more stable complexes with these humic fractions. In case of $\mathrm{Zn}$ shows greater stability at $\mathrm{pH} 8.0$ and above. Thus these humic fractions can be used as carrier materials especially supply of micronutrients to in crop nutrition as these also prevents the loss of nutrients from leaching by forming complex with metal ions like cationic micro nutrients.

\section{Introduction}

The humus formation is a composite of the individual processes like, mineralization, decomposition, humification and putrefaction (Choudhuri et al., 2010).

The quantitative changes in soil humus are determined by the relation between the processes of synthesis and decomposition of the organic matter. They are dynamic and are expressed specifically under particular soil, climatic conditions and systems of agriculture (Koteva and Kostadinova, 2014). Investigations into humus focus not only on direct management, but also into sustainable management practices that define the dynamic of humus in the soil. It is known that many factors have an impact on the humification and mineralization of humus in soil, of which precipitation is one of the most important. Humification and mineralization takes place slowly under conditions in which the amount of precipitation is high and the temperature is low (Tajnsek et al., 2013). Humic substances (HS) are the major source of energy and nutrients for soil biota. They are also charge carriers and play vital role in complexing organic compounds and adsorbents in controlling the toxicity, transport and fate of a 
variety of pollutants (Ahamadou et al., 2013). These are yellow or brown to black coloured, acidic, poly disperse substances of relatively high molecular weight (Stevenson, 1982). Based on solubility, the humic substances are broadly divided into three classes. (a) Humic acid (alkali soluble and acid insoluble) (b) Fulvic acid (acid and alkali soluble) and (c) Humin (insoluble in both acid and alkali) (Waiker et al., 2004; Kar et al., 2007; Srilatha et al., 2013; Ramalakshmi et al., 2013 and Nagamadhuri et al., 2013).

One of the most prominent features of humic substances is its complex formation through the functional groups, like carboxylic ($\mathrm{COOH})$, phenolic $(-\mathrm{OH})$, amino $(-\mathrm{NH} 3)$ and carbonyl $(\mathrm{C}=\mathrm{O})$ (Datta et al., 2001, Srilatha, 2001, Kar et al., 2007 and Ghabbour and Davies, 2009) with polyvalent metal ions, viz. $\mathrm{Cu}^{2+}, \mathrm{Zn}^{2+}, \mathrm{Mn}^{2+}$ and $\mathrm{Fe}^{2+}$ etc. with different stability constants i.e. solubility in water, depending on the nature of metal ions and organic ligands. The complex formation reactions between metal ions and humic substances are helpful in understanding the problems of plant nutrition (Stevenson et al., 1993). During complexation, numerous compounds including humic acid and fulvic acid are involved which control the distribution and supply of micronutrients to plant roots and interact with metal ions through their functional groups forming metal complexes of varying stabilities.

The magnitude of $\mathrm{pH}$ drop on addition of metal ion to aqueous solution of humic acid and fulvic acid are indicated by potentiometric titrations. Potentiometric measurements have been extensively used to provide information on contribution of metal complexes. From several studies it was indicated that the $\mathrm{pH}$ effect is as much a property of metal complex as its absorption intensity. Potentiometric measurements have been claimed to be convenient way to study the metal -HA and metal -FA interactions (Erdogan et al., 2007; Mina et al., 2004 and Pandeya and Singh 2000). Potentiometric titration curves information along with the buffer effects obtained in titration curves were taken as an indication of complex formation. These potentiometric titration curves are simple, rapid and provide information on relative tendencies of metals to form complexes. Keeping this in view the present study was conducted to characterize humic and fulvic acids in presence and absence of metal ions by using potentiometric methods.

\section{Materials and Methods}

The present study was carried out at the laboratory to characterize the complex formation of humic fractions with metal ions at Department of Soil Science and Agricultural Chemistry, College of Agriculture, Rajendranagar.

Humic acid (HA) and fulvic acid (FA) components of humus are extracted from farmyard manure using the classical fractionation procedures based on their solubility characteristics (Kononova, 1966).

For potentiometric titrations, one hundred milligrams of HA/FA were dissolved in $25 \mathrm{ml}$ of distilled water and was titrated against 0.1 $N \mathrm{NaOH}$ potentiometrically on digital $\mathrm{pH}$ meter to $\mathrm{pH}$ 12.0. For potentiometric titration of HA/FA both in presence and in absence of metal ions, humic acid/fulvic acids were dissolved in $0.1 \mathrm{~N} \mathrm{NaOH}$ to give a final concentration of $5 \mathrm{mg}$ sample per ml of $0.1 \mathrm{~N}$ $\mathrm{NaOH}$. Ten ml of above solution was taken in to $100 \mathrm{ml}$ beakers, to which $25 \mathrm{ml}$ of $0.1 \mathrm{~N}$ $\mathrm{KCl}$ was added in each case. Then the $\mathrm{pH}$ of the sample was adjusted to 3.0 by the addition of $0.1 \mathrm{~N} \mathrm{NaOH}$ (or) $0.1 \mathrm{~N} \mathrm{HCl}$, after which the volume of solution in each case was made up to $50 \mathrm{ml}$ with $0.1 \mathrm{~N} \mathrm{KCl}$. The $\mathrm{NaOH}$ was added in increments of about $0.05 \mathrm{ml}$ and the 
change in $\mathrm{pH}$ of the system was recorded by digital $\mathrm{pH}$ meter.

For the potentiometric titration in the presence of metal ion, $4 \mathrm{ml}$ solution of $0.05 \mathrm{~N}$ of appropriate metal ions ( $\mathrm{Zn}$ (II), $\mathrm{Cu}$ (II), Mn (II) and $\mathrm{Fe}$ (II)) was added to the sample to supply $100 \mu$ moles of metal ions. Similarly $100 \mu$ moles of metal ions were also titrated alone for comparison.

\section{Results and Discussion}

\section{Potentiometric titration of humic acid ad} fulvic acid

Potentiometric titrations have been used to characterize the acidic functional groups in humic and fulvic acids. Potentiometric titration curves of humic acid and fulvic acid presented in figure 1. There was a gradual increase in $\mathrm{pH}$ with the addition of $\mathrm{NaOH}$ indicating high buffering capacity of these humic fractions.

The curves obtained for both humic acid and fulvic acid were sigmoidal in nature and suggested that these substances behave as weak acid polyelectrolytes. These results were in consistence with results reported by Ramalakshmi et al., (2013), Ghatak et al., (2004) and Nagamadhuri et al., (1998).

\section{Titration of metal ions with alkali}

The presence of inflections in the titration curves indicated the oxidation of metal ions and formation of metal hydroxides. The two inflections in the curves at $\mathrm{Cu}$ (II) at $\mathrm{pH} 4.6$ and 8.2, at $\mathrm{pH} 8.6$ for $\mathrm{Zn}$ (II), at $\mathrm{pH} 3.9$ and 8.1 for $\mathrm{Fe}$ (II) and at $\mathrm{pH} 6.2$ for Mn (II).

It is evident that corresponding metal hydroxides were formed as indicated by inflection in titration curves (Fig. 2). These results are in line with those reported for
$\mathrm{Cu}(\mathrm{II}) \quad$ (Schnitzer and Skinner, 1963; Stevenson, 1977), Zn(II) (Srilatha, 2001), $\mathrm{Fe}(\mathrm{II})$ (Relan et al., 1990) and $\mathrm{Mn}(\mathrm{II})$ (Schnitzer and Khan, 1972).

\section{Titration of humic acid and metal humates}

Titrations curves of humic acid and corresponding metal-humates are shown in (Fig. 3). The close perusal of graph indicated no inflection in the titration curve of humic acid and a close look at the titration curves of metal-humates indicated that the formation of metal hydroxides was suppressed when metal ions are added to humic acid and the absence of inflection was taken as an index of complex formation.

In the case of $\mathrm{Zn}$ complexes, the greatest stability was found for $\mathrm{pH}$ values of 7.0 and 8.0 , which correspond to those of neutral and alkaline soils. This fact suggests the intervention of strongly acidic carboxyl and phenol groups in the complexing process at these $\mathrm{pH}$ levels. At $\mathrm{pH}$ 6.0, stability was also important although lower than at alkaline $\mathrm{pH}$ levels. Stability at pH 9.0 decreased significantly, probably because of the competition between the complexing process and the formation of the insoluble hydroxide of $\mathrm{Zn}$ i.e., $\mathrm{Zn}(\mathrm{OH})_{2}$ (Mina et al., 2004).

The displacement in curve of humic acid in presence of metal ion was wider at higher $\mathrm{pH}$ and the reverse was true at lower $\mathrm{pH}$. The reduction in $\mathrm{pH}$ on addition of humic acid in the presence of various metal ions followed the order $\mathrm{Cu}$ (II) $>\mathrm{Mn}$ (II) $>\mathrm{Fe}$ (II) $>\mathrm{Zn}$ (II).

\section{Titration of fulvic acid and metal-fulvates}

The titration curves of fulvic acid and metal fulvates are presented in (Fig. 4). The apparent monobasic character of fulvic acid was evident from the sigmoidal shape of their titration curves. 
Fig.1 Potentiometric titration curves of humic acid (FYM-HA) and fulvic acid (FYM-FA)
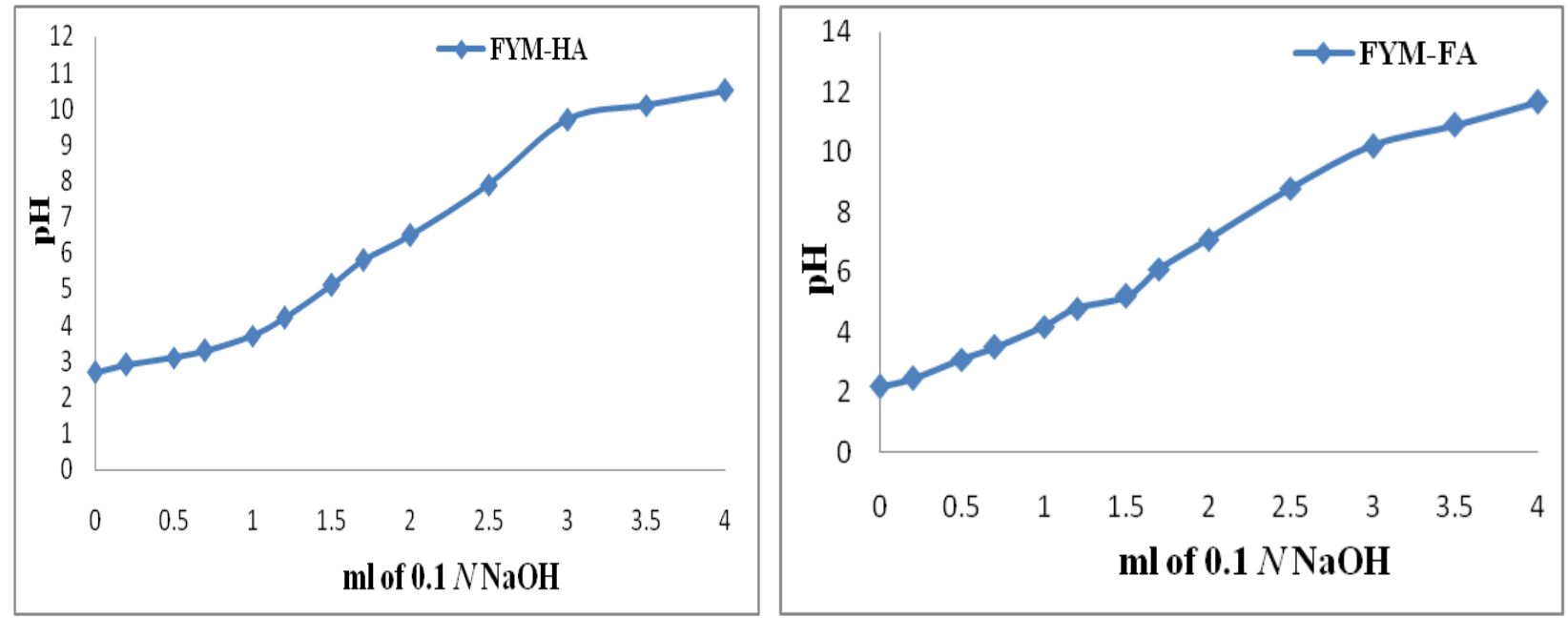

Fig.2 Potentiometric titration curves of metal ions

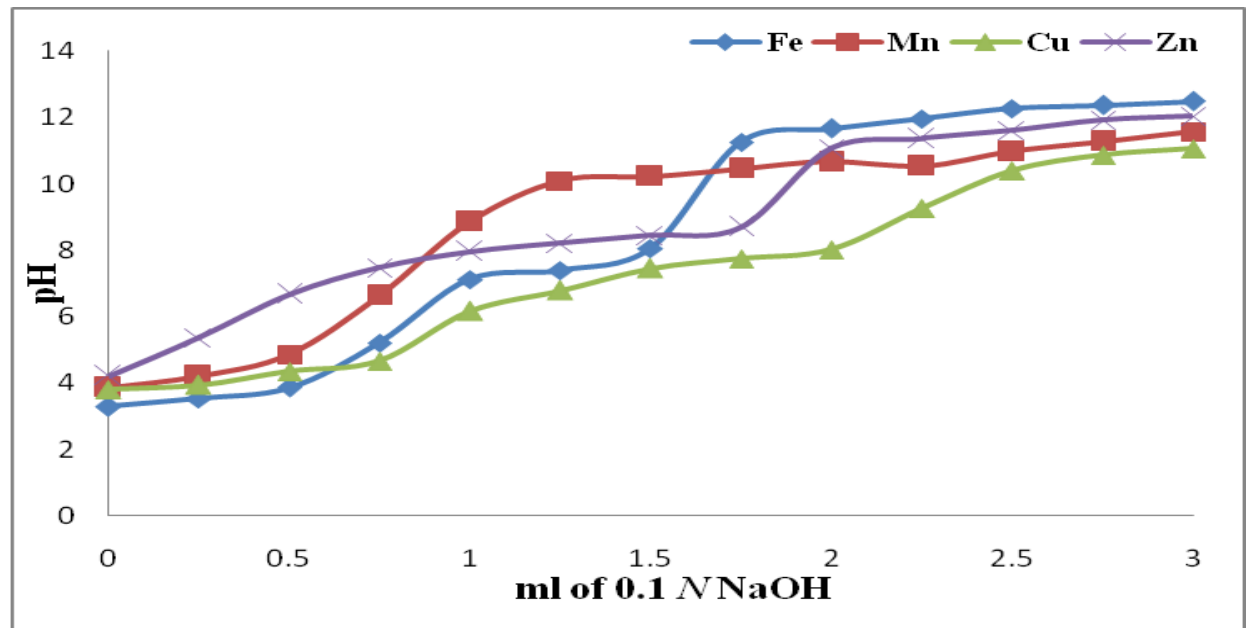

Fig.3 Potentiometric titration curves of humic acid and metal humates

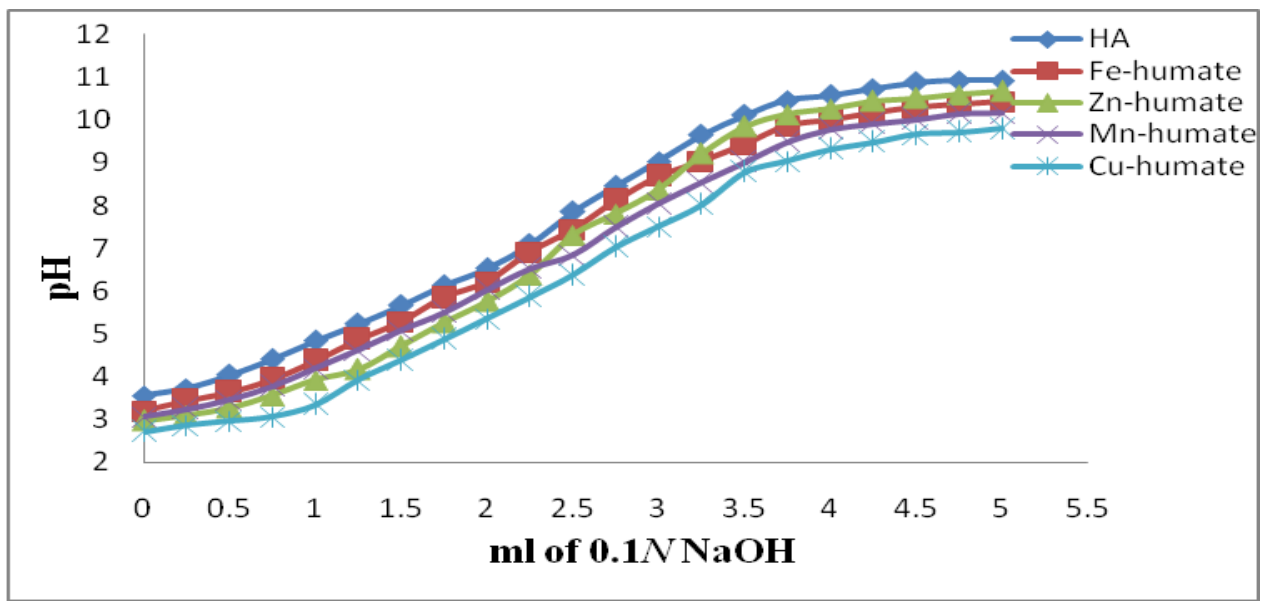


Fig.4 Potentiometric titration curves of fulvic acid and metal fulvates

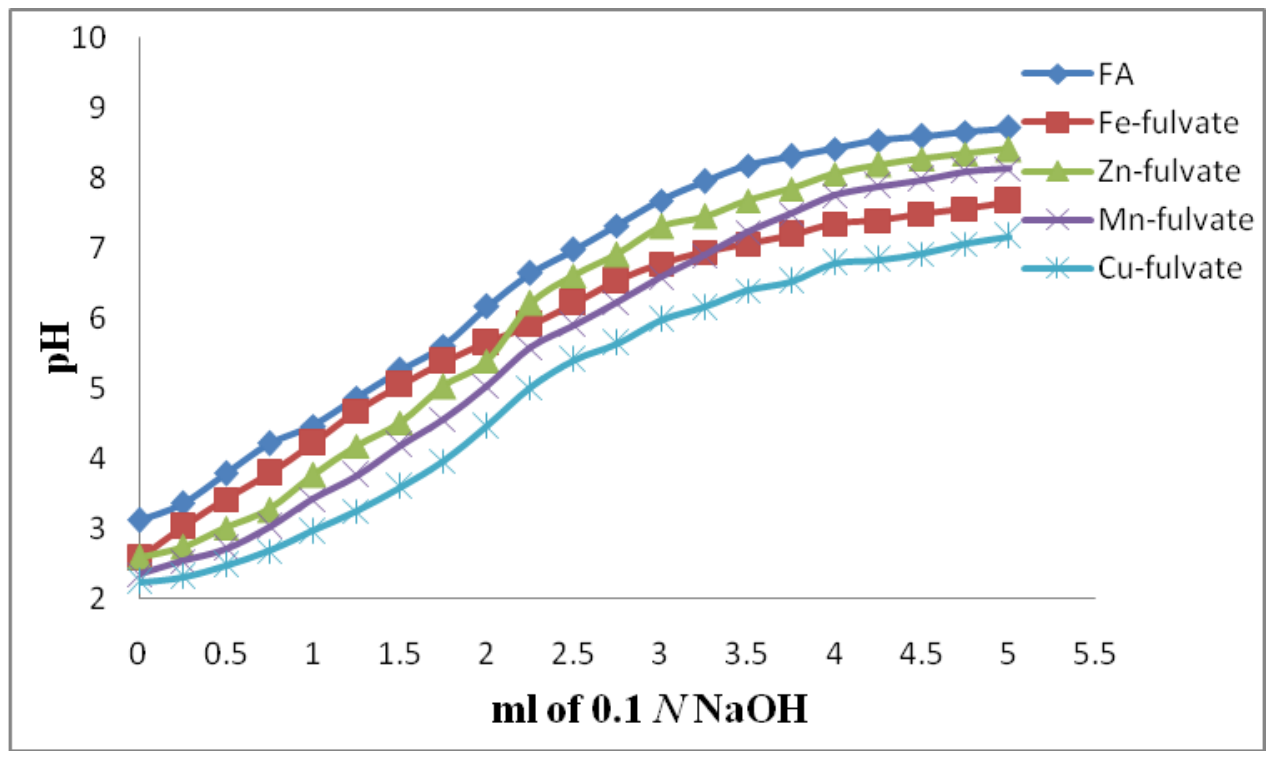

Absence of inflection corresponding to formation of metal hydroxides indicates the formation of metal complexes. The potentiometric titration curves of fulvic acids in the absence and presence of $\mathrm{Zn}$ show that all the points of titration curves, the $\mathrm{pH}$ of the fulvic acid zinc complex was less than the corresponding $\mathrm{pH}$ of fulvic acid alone.

Humic acid/ fulvic acid contains large number of functional groups. Several $\mathrm{H}^{+}$ions are displaced during complexation leading to drop in $\mathrm{pH}$ of solution. Similar results were also reported by Pandeya and Singh, (2000). The $\mathrm{pH}$ drop can ascribed to that Fe forms a complex with fulvic acid ligands which will be accompanied by a drop in the $\mathrm{pH}$ of the system. The drop in the $\mathrm{pH}$ of the solutions may thus be attributed to the formation of fulvic acid iron complexes and release of protons from the functional groups.

From the comparison of metal-humic substance complexes, it is clear that displacement of curves of fulvic acid was higher than that of humic acid. This could be attributed to higher hydrophobic nature of fulvic acid as compared to humic acid and thus fulvic acid has greater tendency to form complexes with metal ions. Similar results were also reported by Reddy et al., (1999).

From the potentiometric curves it is evident that the reduction in $\mathrm{pH}$ on addition of humic acid in the presence of various metal ions followed the order) $\mathrm{Cu}$ (II) $>\mathrm{Mn}$ (II) $>\mathrm{Fe}$ (II) $>\mathrm{Zn}$ (II) while fulvic acid in presence of metal ions followed the order $\mathrm{Cu}$ (II) $>\mathrm{Mn}$ (II) $>\mathrm{Fe}$ (II) $>\mathrm{Zn}$ (II). Among the metals $\mathrm{Fe}$ metal ion forms a stable complex indicating the absence of inflection in potentiometric curves booth in humic and fulvic acids.

From the comparison of metal-humic substance complexes, it is clear that displacement of curves of fulvic acid was higher than that of humic acid due to higher hydrophobic nature of fulvic acid as compared to humic acid and thus fulvic acid has greater tendency to form complexes with metal ions.

\section{References}

Ahamadou, B., Huang, Q., Yaping, L and Iqbal, J. 2013. Composition and 
structure of humic substances in longterm fertilization experimental soils of southern china. Journal of Soil Science and Environmental Management. 4(4): 77-86

Choudhuri, N.B., Sinha, B and Mudhopadhyay, P. 2010. Study on the nature, composition and movement of humic substances throughout different horizons in some inceptisol profiles. Indian Journal of Agricultural Chemistry. XXXXIII (1 and 2): 35-47.

Datta, A., Sanyal, S.K and Saha, S. 2001. A study on natural and synthetic humic acids and their complexing ability towards ed. Plant and Soil. 235: 115125.

Erdogan, S., Baysal, A., Akba, O and Hamamci, C. 2007. Interaction of metals with humic acid isolated from oxidized coal. Polish Journal of Environmental Studies. 16 (5): 671-675.

Ghabbour, E.A and Davies, G. 2009. Spectrophotometric analysis of fulvic acid solutions: A second look. Annals of Environmental Science. 3: 131-138.

Ghatak, H., Mukhopadhyay, S.K., Jana, T.K., Sen, B.K and Sen, S. 2004. Interactions of $\mathrm{Cu}$ (II) and Fe (III) with mangal humic substances studied by synchronous fluorescence spectroscopy and potentiometric titration. Wetlands Ecology and Management. 12: 145-155.

Kar, D.D., Ghosh, D and Srivastava, P.C. 2007. Efficacy evaluation of different zinc-organo complexes in supplying zinc to maize (Zea mays L.) plant. Journal of the Indian Society of Soil Science. 55 (1): 67-72.

Kononova, M.M. 1966. Soil Organic Matter. Press. 400-410.

Koteva, V and Kostadinova, S. 2014. Changes of the humus status of Pellic Vertisol (FAO) soil type under longterm growing of field crops in a stationary trial without fertilization.
Agricultural Science and Technology. 6 (2): 211 - 214.

Mina, J.M.G., Antolin, M.C and Diaz, M.S. 2004. Metal-humic complexes and plant micronutrient uptake: a study based on different plant species cultivated in diverse soil types. Plant and Soil. 258:57-68.

Nagamadhuri, K.V., Rao, P.C and Raju, A.S. 1998. Influence of natural vegetation and continuous cultivation of organic matter content in soils of Rajendranagar, Hyderabad, India. Paper presented at $16^{\text {th }}$ World Congress of Soil Science held at Agropolis, Montpellier Cedex, France during August 22-26, 1998.

Nagamadhuri, K.V., Rao, P.C., Prathima, T., Suresh, K., Kumar, K.V.K and Giridhar V. 2013. Effect of long-term application of fertilizers on soil organic matter. International Journal of Applied Biology and Pharmaceutical Technology. 4(2): 0976-4550.

Pandeya, S.B and Singh, A.K. 2000. Potentiometric measurement of stability constants of complexes between fulvic and carboxylate and $\mathrm{Fe}^{3+}$. Plant and Soil. 223: 13-21.

Ramalakshmi, Ch. S., Rao, P.C., Sreelatha, T., Padmaja, G and Madhavi, M. 2013. Nitrogen use efficiency and production efficiency of rice under integrated nutrient management. Journal of Rice Research. 4 (1\&1): 42-59.

Reddy, K.S., Chandrasekhar Rao, $\mathrm{P}$ and Sreenivasa Raju, A. 1999. Interaction of humic acid fractions obtained from alfisols and vertisols of Acharya N.G. Ranga Agricultural University, Rajendranagar campus by absorption spectroscopic methods. Journal of Environmental Biogeochemistry (accepted for publication).

Relan, P.S., Chawala, $M$ and Sharma, A. 1990. Formation constants of some 
micronutrients and heavy metal complexes with fulvic acid from farmyard manure. International Journal of Tropical Agriculture. 8 (3): 193-197.

Schnitzer, M and Khan, S.U. 1972. Humic substances in the environment. MarcelDekker, New York.

Srilatha, M. 2001. Characterization of humic substances and their interactions with metal ions in relation to their availability to rice. M.Sc. (Ag.) thesis submitted to Acharya N.G. Ranga Agricultural University, Rajendranagar and Hyderabad.

Srilatha, M., Rao, P.C., Sharma, S.H.K and Padmaja, G. 2013. Physico - chemical characterisation of humic substances under long - term application of fertilizers and manures in rice - rice cropping sequence in an Inceptisol.
International Journal of Advanced Research. 1 (10): 343-348.

Stevenson, F.J., Lanath, F.A and Brar, M.S. 1993. Stability constants of $\mathrm{Cu}$ (II)humate complexes: comparison of select models. Soil Science. 155 (2): 7791.

Tajnsek, A., Cergan, Z and Barbara, C. 2013. Results of the long-term field experiment IOSDV Jable at the beginning of the 21st century. Archives of Agronomy and Soil Science. 59 (8): 1099-1108.

Waikar, S.L., Malewar, G.U., More, S.D and Kausadikar, H.K. 2004. Humic substances and functional groups of soil humus reserve developed under varied agro ecological units of south central part of Maharashtra. Journal of the Indian Society of Soil Science. 52 (2): $147-150$.

\section{How to cite this article:}

Rajashekhar, D., M. Srilatha, P. Chandrasekhar Rao, S. Harish Kumar Sharma and Bhanu Rekha, K. 2018. Characterization of Metal Ion Complexes with Humic Fractions of Farmyard Manure by Potentiometric Titrations. Int.J.Curr.Microbiol.App.Sci. 7(04): 3322-3328. doi: https://doi.org/10.20546/ijcmas.2018.704.376 